\title{
Impact of environmental factors and Sahara dust intrusions on incidence and severity of COVID-19 disease in Spain. Effect in the first and second pandemic waves
}

\author{
Cristina Linares ${ }^{1} \cdot$ Dante Culqui $^{1} \cdot$ Fernando Belda ${ }^{2}$ - José Antonio López-Bueno ${ }^{1} \cdot$ Yolanda Luna $^{2}$. \\ Gerardo Sánchez-Martínez ${ }^{3}$ - Beatriz Hervella ${ }^{2}$. Julio Díaz ${ }^{1}$
}

Received: 19 January 2021 / Accepted: 28 April 2021 / Published online: 16 May 2021

(C) The Author(s), under exclusive licence to Springer-Verlag GmbH Germany, part of Springer Nature 2021

\begin{abstract}
Scientific evidence suggests that Saharan dust intrusions in Southern Europe contribute to the worsening of multiple pathologies and increase the concentrations of particulate matter (PM) and other pollutants. However, few studies have examined whether Saharan dust intrusions influence the incidence and severity of COVID-19 cases. To address this question, in this study we carried out generalized linear models with Poisson link between incidence rates and daily hospital admissions and average daily concentrations of $\mathrm{PM}_{10}, \mathrm{NO}_{2}$, and $\mathrm{O}_{3}$ in nine Spanish regions for the period from February 1, 2020 to December 31, 2020. The models were adjusted by maximum daily temperature and average daily absolute humidity. Furthermore, we controlled for trend, seasonality, and the autoregressive nature of the series. The variable relating to Saharan dust intrusions was introduced using a dichotomous variable, NAF, averaged across daily lags in ranges of 0-7 days, 8-14 days, 14-21 days, and 22-28 days. The results obtained in this study suggest that chemical air pollutants, and especially $\mathrm{NO}_{2}$, are related to the incidence and severity of COVID-19 in Spain. Furthermore, Saharan dust intrusions have an additional effect beyond what is attributable to the variation in air pollution; they are related, in different lags, to both the incidence and hospital admissions rates for COVID-19. These results serve to support public health measures that minimize population exposure on days with particulate matter advection from the Sahara.
\end{abstract}

Keywords COVID-19 $\cdot$ Saharan Dust $\cdot$ Morbidity $\cdot \mathrm{PM} 10 \cdot \mathrm{NO}_{2} \cdot$ Hospital admissions

\section{Introduction}

The 2019 coronavirus (COVID-19) outbreak in Wuhan, China was declared a pandemic by the World Health Organization (WHO) on March 11, 2020 (WHO, 2020a). Since that time, multiple studies have been carried out that aim to explain the different behavior of the virus in terms of transmission and severity that has been observed in different locations around the world. Studies

Responsible Editor: Gerhard Lammel

Julio Díaz

j.diaz@isciii.es

1 National School of Public Health, Carlos III Institute of Health (ISCIII), Avda Monforte de Lemos 5, 28029 Madrid, Spain

2 State Meteorological Agency (AEMET), Madrid, Spain

3 The UNEP DTU Partnership, Copenhagen, Denmark take into account environmental factors such as temperature and humidity (Holtmann et al. 2020; CDC 2020; Lipsitch et al. 2020; Tobías and Molina 2020; Sajadi et al. 2020), solar radiation (Yao et al. 2020), and wind velocity (Islam et al. 2020).

If we take into account that the most severe symptoms have been observed in people over age 65 (Remuzzi and Remuzzi 2020) with prior conditions such as cardiovascular diseases (Li et al. 2020; Onder et al. 2020) and respiratory, endocrine, and digestive (Sohrabi et al. 2020; Wang et al. 2021) problems, chemical air pollution seems to be one of the factors that could be related to the development and severity of the disease (Contini and Costabile 2020; Marquès et al. 2021). Air pollution predominantly affects these age groups and these conditions in particular (Landrigan et al. 2018). Thus, in recent months, multiple studies have been published using different methodologies that relate air pollution to the incidence of COVID-19 (Bashir et al. 2020; Fronza et al. 2020; Jiang et al. 2020; Ogen 2020) and its severity (Wang et al. 2021; 
Saez et al. 2020; Bilal et al. 2020; Zoran et al. 2020; Travaglio et al. 2021; Magazzino et al. 2020; Dominici et al. 2020). In addition, studies carried out in Italy (Setti et al. 2020) have pointed out that particles of up to 10 micros $\left(\mathrm{PM}_{10}\right)$ could act as a vector for transmission of the SARS-CoV-2 virus. On the other hand, there are studies that conclude that SARS-CoV-2 are not detectable in outdoors, in Italy (Chirizzi et al. 2021) and other countries (Liu et al. 2020; Dunker et al. 2021; Passos et al. 2021).

Despite much research on the transmission process and severity of the virus, there are practically no studies that analyze the role of a natural and relatively frequent phenomenon in the South of Europe, Saharan dust advection (Stafoggia et al. 2016). This natural event is an especially interesting topic for analysis for two reasons. First, the arrival of Sarahan dust produces a statistically significant increase in the concentrations of particulates and other contaminants that have an effect on transmission and severity, as has been shown previously. Furthermore, the days with Saharan dust intrusions have been shown to have a clear additional incidence in terms of the worsening of cardiovascular and respiratory diseases (Stafoggia et al. 206; Díaz et al. 2017; Pérez et al. 2012), especially among the most vulnerable groups (Jiménez et al. 2011). Therefore, the objective of this study was to analyze the impact of environmental factors and Sahara dust intrusions on incidence and severity of COVID-19 disease in Spain. The period of study contain the first and second pandemic waves.

\section{Materials and methods}

\section{Dependent and independent variables}

\section{Dependent variables}

The dependent variables were calculated based on the number of positive cases of COVID-19. Cases diagnosed as positive for COVID-19 were defined based on a positive PCR test result. Cases thus defined refer to daily cases that occurred in the regions analyzed during the time period from February 1, 2020 through December 31, 2020. The state of alarm and subsequent confinement of the population went into effect on March 14, along with measures restricting movements and social interactions (BOE 2020a), and they remained in effect until June 21 (BOE 2020b).

The data analyzed corresponded to the number of cases diagnosed as COVID-19 positive and the number of urgent hospital admissions due to COVID-19 and were provided by the National Center for Epidemiology at the Carlos III Health Institute. The population data at the province level were provided by the National Statistics Institute (INE). Based on these data, we calculated the following rates:

Incidence rate of COVID-19 per 1,000,000 inhabitants

: (Number of positive COVID cases/population)

$\times 1,000,000$ inhabitants.

Rate of urgent hospital admissions due to COVID-19 per 1,000,000 inhabitants: (Number of urgent hospital admissions due to positive COVID-19 cases/population) $\times 1,000,000$ inhabitants.

\section{Independent variables}

The independent variables were made up of both meteorological and air pollution data, as well as, the days with Saharan dust intrusion that occurred during the study period.

The meteorological data were the daily maximum temperature values (Tmax) and daily average relative humidity (HR) in percent form. Based on daily average relative humidity and daily average temperature, the values of daily average absolute humidity (AH) were obtained in $\mathrm{g} / \mathrm{m}^{3}$ (Gupta et al. 2020). Maximum daily temperature and daily average absolute humidity were used because they presented better behavior with the COVID-19 variables analyzed than daily minimum and mean temperature and relative humidity (Xie and Zhu 2020).

These values made up the average values of the observations corresponding to the AEMET stations located in the regions considered in the study. They were provided by the State Meteorological Agency (AEMET).

Air pollution data were made up of the average daily values of concentrations of $\mathrm{PM}_{10}, \mathrm{NO}_{2}$, and $\mathrm{O}_{3}$ in $\mu \mathrm{g} / \mathrm{m}^{3}$, obtained as an average of the values measured in stations located in the different regions analyzed. These data were provided by the Ministry for Ecological Transition and Demographic Challenge (MITECO).

The classification of the days with Saharan dust intrusion was determined based on information provided by the Ministry for Ecological Transition and Demographic Challenge in Spain (MITECO 2020). According to MITECO methodology, Spain is divided into nine areas: North, North-East, North-West, Center, South-East, SouthWest, East, Canary Islands, and Balearic Islands, as shown in Fig. 1. In order to identify the existence of a day with Saharan dust intrusion, a first evaluation of the advection process was carried out, based on an analysis of retro-trajectories of air masses, synoptic maps, satellite images, and numerical prognosis models for mineral matter. Later, there was an evaluation of the true impact of African dust in surface level registries, based on a statistical analysis applied to time series for average daily values of $\mathrm{PM}_{10}$ obtained at regional measurement stations in each of the studied areas. This is one of the 

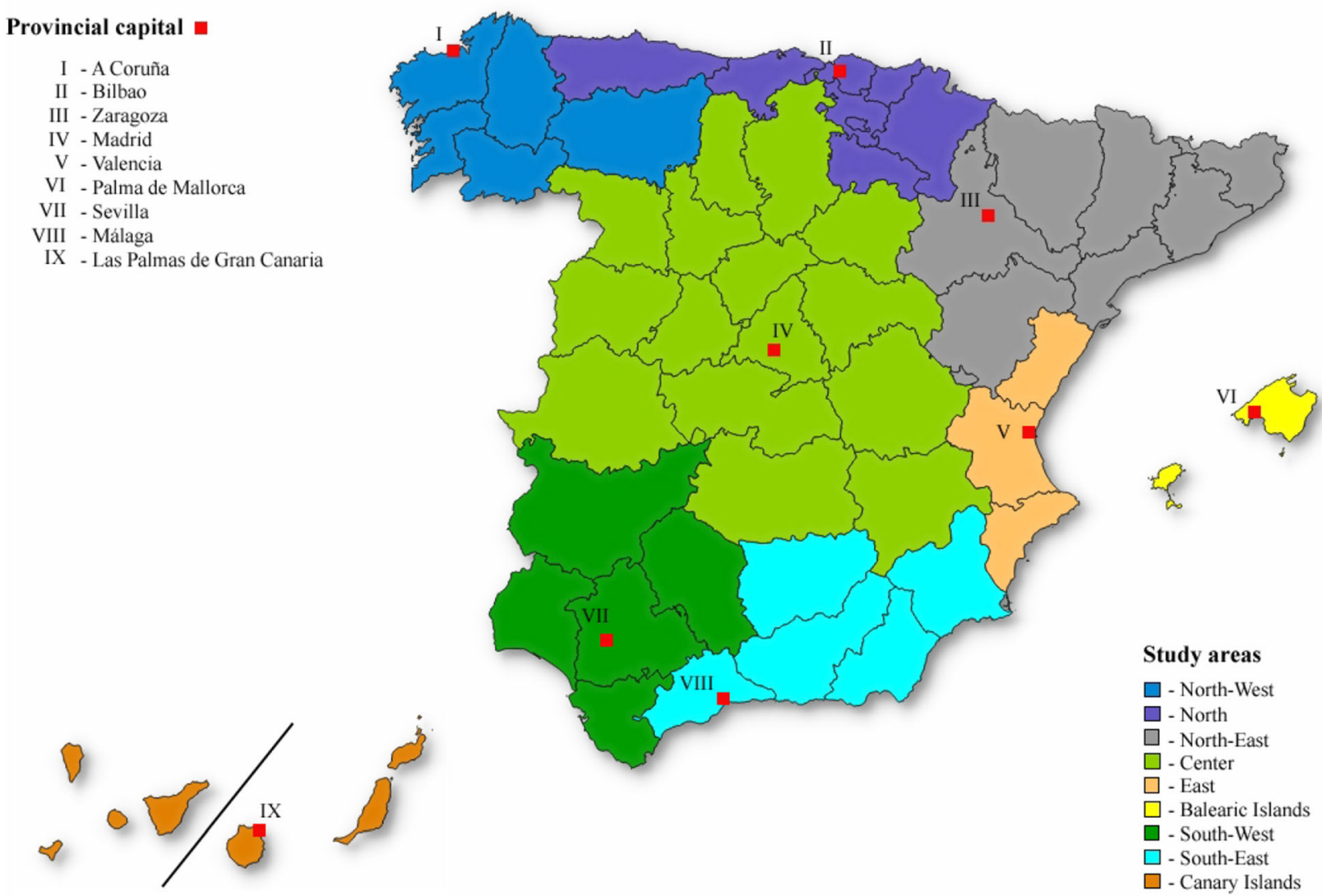

Fig. 1 Location of the study regions and location of the province capitals selected for participation in the study

official methods recommended by the European Commission for the evaluation of the occurrence of dust intrusions of African origin (CSWP 2011).

\section{Variables used in the analysis}

In each of the nine regions described above, a representative province was selected based on the existence and quality of air pollution data, meteorological data and variables related to COVID-19. For the North region, the selected province was Vizcaya (provincial capital Bilbao); Zaragoza province was selected for the North-East region; A Coruna was selected for the North-West region; Madrid was selected for the Center region; Málaga was selected for the South-East region; Sevilla was selected for the South-West region; Valencia was selected for the East region; Las Palmas de Gran Canaria was selected for the Canary Islands; and Palma de Mallorca was selected for the Balearic Islands region (see Fig. 1). This selection has been used in prior studies related to the incidence of Saharan dust and morbidity and mortality in Spain (Moreira et al. 2020; Díaz et al. 2017; Russo et al. 2020).

In order to take into account the days with Saharan dust advection, a dichotomous variable was calculated, North African intrusions, named NAF, equals 1 on a day with advection and 0 on a day without it. Based on daily NAF, we calculated average values with lags of 0 to 7 days (NAF:0_7); 8 to 14 days (NAF:8_14); 15 a 21 days (NAF:15_21); and 22 to 28 days (NAF:22_28) with the objective of analyzing the lagged behavior of these intrusions on the COVID-19 variables registered.

\section{Analysis methodology}

For each of the mentioned regions, generalized linear models with Poisson link (GLM) were carried out between the dependent (positive COVID rates) and independent (environmental) variables. In these models, we controlled for the series trend and seasonality for $120,90,60$, and 30 days and the autoregressive nature of the series. Also, we controlled for weekly seasonality by including the days of the week as dummy variables in the models. For example, when the data corresponded to Tuesday, the value in the cell data corresponding to the variable "day of the week" was equal to 1 ; and all the other weekdays for the same data were zero.

GLM were carried out between each dependent variable and the average daily values of the independent variables. In this way, time lags were established that produced statistically 
significant associations between the dependent variables and the independent variables.

The range of lag days considered in the analysis was from 0 to 28 days, to account for the time that took place between the occurrence and worsening of symptoms and arrival at the hospital (Lauer et al. 2020; WHO 2020b). A weekly distributed lag model was used. In a first step, the lags were introduced corresponding to the independent variables, lagged from 0 to 7 days. In a second step, the lags corresponding to 8 to 14 days were introduced, keeping the variables lagged that were statically significant in the first step, and so on up to 28 days, to complete the range of lag days considered in the analysis. This methodology has been used in other, similar studies (Díaz et al. 2021).

Finally, all variable models were carried out between all of the dependent and independent variables, introducing the control variables described. Based on the absolute values of the estimators, relative risks (RR) were calculated in the form RR $=\mathrm{e}^{\beta}$ with $\beta$ as the absolute value of the estimator obtained in the Poisson modeling. A negative coefficient in the estimator indicated that an increase in the independent variable was associated with a decrease in the dependent variable. The $\mathrm{RR}$ was calculated using an increase of $1 \mu \mathrm{g} / \mathrm{m}^{3}$ in $\mathrm{PM}_{10}$, $\mathrm{NO}_{2}$, and $\mathrm{O}_{3} ; 1^{\circ} \mathrm{C}$ in the maximum temperature (Tmax) and $1 \mathrm{~g} / \mathrm{m}^{3}$ in the absolute humidity (AH) value.

In the case of the NAF variable, the RR values obtained referred to increases of one unit in the values of NAF. That is to say, if, during the lagged days analyzed, all of the days had Saharan dust intrusion, the value of NAF would be equal to one, and if there had not been any days, it would be zero. In cases where some days had intrusion, the value of NAF would oscillate between zero and one, given that it refers to the weekly average of a dichotomous variable.

We used a back-stepwise process for variable selection, and statistical significance was set at a $p$ value of $p<0.05$. Over- and under-dispersion were controlled for.

\section{Results}

Table 1 shows the descriptive statistics that correspond to the dependent and independent variables analyzed in this study. The values of these variables for the days with Saharan dust intrusion $(\mathrm{NAF}=1)$, and those without intrusion $(\mathrm{NAF}=0)$ appear marked with an asterisk when the values of the independent variables present statistically significant differences between the days with and without Saharan dust advection.

A Coruna is not shown, given that the number of days with Saharan dust intrusion in the period was 10 , which was lower than the limit established for the region. (There had to be intrusion on at least $10 \%$ of days.) The greatest percentage of days with Saharan dust intrusion was in Las Palmas de Gran Canaria (44.7\%), Málaga (40\%), Sevilla (27.2\%), and
Valencia (26\%), and the lowest levels were in Bilbao (12.9\%) and in Palma de Mallorca (12.2\%).

As shown in Table 1, in all of the regions considered, the values of $\mathrm{PM}_{10}$ were greater on the days where $\mathrm{NAF}=1$ than on the days without dust, and this difference was statistically significant in all cases. Also for ozone concentrations, the days with $\mathrm{NAF}=1$, the values were greater with statically significance in all regions except in Las Palmas de Gran Canaria and Palma de Mallorca. The same behavior is founded for Tmax values. In the case of $\mathrm{AH}$ values, the value was greater, and statistically significant, on days with intrusion in all the regions except in Las Palmas de Gran Canaria.

The results of the multivariate models in which the whole group of variables was introduced appear in Table 2. It is worth noting that daily concentrations of $\mathrm{NO}_{2}$ are the air pollution variable that appears most frequently related to the dependent variables. In relation to the incidence rate, it appears in eight of the regions, compared to four which are related to average daily concentrations of $\mathrm{PM}_{10}$; ozone concentrations only appears in four regions. In relation to hospital admissions, $\mathrm{NO}_{2}$ appears to be related in six of the regions; $\mathrm{O}_{3}$ and $\mathrm{PM}_{10}$ in three. The RR for $\mathrm{NO}_{2}$ concentrations was greater than the RR founded for $\mathrm{PM}_{10}$ and $\mathrm{O}_{3}$, in all regions, in both incidence rates and hospital admissions rate.

For the meteorological variables, Tmax was related to the incidence rate with a negative sign for six of the regions considered. The same occurred with $\mathrm{AH}$, also with a negative sign. In terms of hospital admissions for COVID-19, Tmax values were associated with a negative sign only in one of the regions and $\mathrm{AH}$ in three. The RR values founded for AH were (in absolute number) higher than Tmax in all regions. In terms of the variable exclusively related to NAF, this variable is associated with incidence rate in seven regions and with hospital admissions in five.

Generally, the lags in which associations appeared for $\mathrm{NO}_{2}$ and $\mathrm{PM}_{10}$ seem to be more short-term for $\mathrm{NO}_{2}$, and in some cases there was even an association at lag 0 , while in the case of $\mathrm{PM}_{10}$, associations were established beginning with lag 8 (except in one). The same was true in the case of $\mathrm{AH}$ and Tmax for which associations were produced, in general, after lag 4-5.

In terms of the NAF variable, Fig. 2 shows the relative risks obtained for the COVID-19 incidence rate for the different NAF lags in which statistically significant associations were established. Similarly, Fig. 3 shows the relative risks for the hospital admissions rate for COVID-19 for the different NAF lags. From a quantitative perspective, the RR associated with values of NAF was greater than those found for the rest of the independent variables analyzed.

\section{Discussion}

In the case of the Saharan desert, the proximity to the source of advection and the path followed by the air masses follow in 


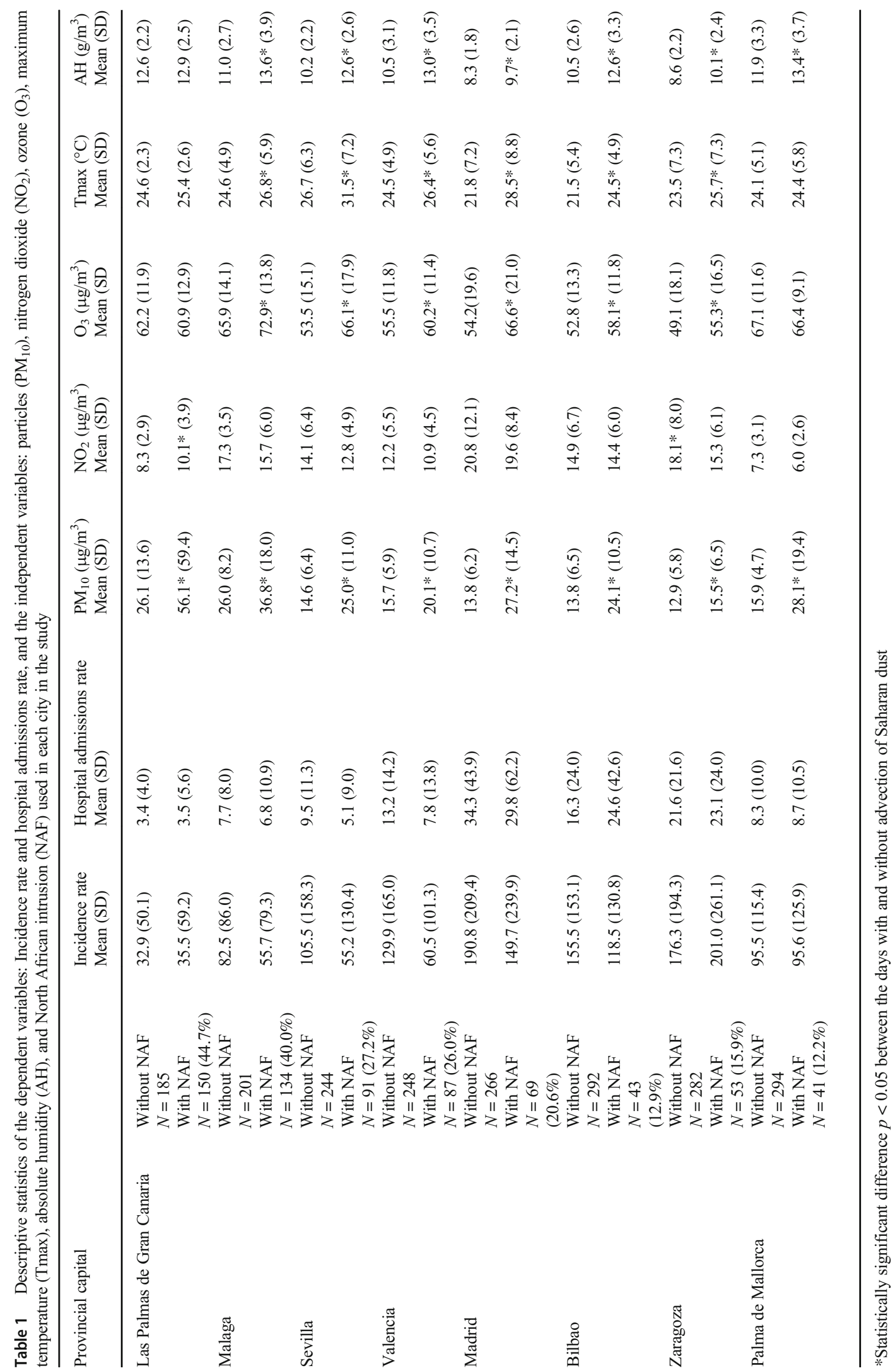


Table 2 Results of the multivariate models by regions, between dependent variables: incidence rate and hospital admissions rate for COVID-19, and the independent variables: particles matter $\left(\mathrm{PM}_{10}\right)$, nitrogen dioxide $\left(\mathrm{NO}_{2}\right)$, Ozone $\left(\mathrm{O}_{3}\right)$, daily maximum temperature
(Tmax), absolute humidity (AH), and North African intrusion (NAF) for its corresponding lags. In brackets appear the lags with statistical significance

\begin{tabular}{|c|c|c|}
\hline Provincial capital & Incidence rate & Hospital admissions rate \\
\hline Las Palmas de Gran Canaria & $\begin{array}{l}\mathrm{NO}_{2}(8,15) \text { RR: } 1.070(1.0251 .16) \\
\mathrm{O}_{3}(27) \text { RR: } 1.007(1.0041 .009)\end{array}$ & $\begin{array}{l}\text { Tmax (9) RR: } 1.129(1.0901 .170) \\
\text { NAF:8_14 RR: } 1.357(1.0961 .682) \\
\text { NAF:22_28 RR: } 1.781(1.4092 .249)\end{array}$ \\
\hline Malaga & $\begin{array}{l}\text { PM10 (21) RR : } 1.003(1.0021 .004) \\
\mathrm{NO}_{2}(0,15,20,28) \mathrm{RR}: 1.070(1.0101 .131) \\
\text { NAF:0_7 RR: } 1.273(1.1781 .377)\end{array}$ & Without effect. \\
\hline Sevilla & 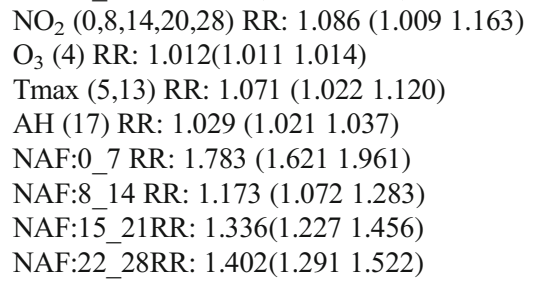 & $\begin{array}{l}\mathrm{PM}_{10} \text { (12)RR: } 1.005 \text { (1.001 1.008) } \\
\mathrm{NO}_{2}(7,28) \text { RR: } 1.025(1.004 \text { 1.047) }\end{array}$ \\
\hline Valencia & 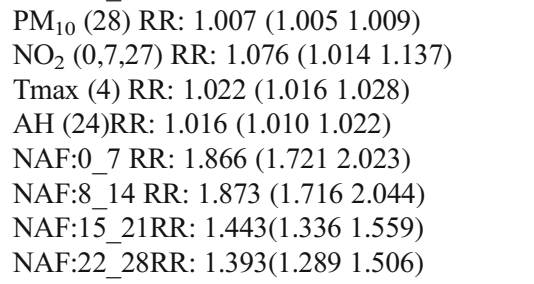 & $\begin{array}{l}\mathrm{PM}_{10}(19,21,24,28) \mathrm{RR}: 1.029(1.0021 .057) \\
\mathrm{NO}_{2}(0,7,27) \mathrm{RR}: 1.043(1.0041 .082) \\
\mathrm{AH}(24) \mathrm{RR}: 1.028(1.0081 .049) \\
\mathrm{NAF}: 8 \_14 \mathrm{RR}: 1.390(1.0041 .925)\end{array}$ \\
\hline Madrid & 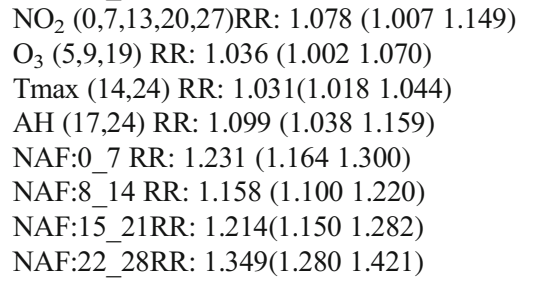 & 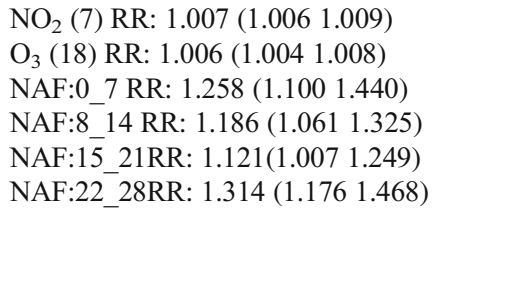 \\
\hline Bilbao & $\begin{array}{l}\mathrm{NO}_{2}(7,22) \mathrm{RR}: 1.019(1.0071 .030) \\
\text { Tmax }(11) \mathrm{RR}: 1.012(1.0091 .016) \\
\mathrm{AH}(17,24) \mathrm{RR}: 1.054(1.0281 .080) \\
\text { NAF:0_7 RR: } 1.139(1.0581 .223) \\
\text { NAF:8_14 RR: } 1.086(1.0071 .172) \\
\text { NAF:22_28RR: } 1.198(1.1181 .284)\end{array}$ & $\begin{array}{l}\mathrm{NO}_{2}(28) \text { RR: } 1.015(1.0111 .019) \\
\text { NAF:0_7 RR: } 2.196(1.7122 .817) \\
\text { NAF:8_14 RR: } 1.761(1.4062 .207) \\
\text { NAF:15_21RR: } 1.696(1.398 \text { 2.059) }\end{array}$ \\
\hline Zaragoza & $\begin{array}{l}\mathrm{PM}_{10}(8) \mathrm{RR}: 1.009(1.007 \text { 1.011) } \\
\mathrm{NO}_{2}(1) \mathrm{RR}: 1.017(1.0161 .019) \\
\mathrm{O}_{3}(25) \mathrm{RR}: 1.006(1.0051 .008) \\
\mathrm{TMax}(4,6,20) \mathrm{RR}: 1.037(1.0111 .163) \\
\mathrm{AH}(8,11,17,28) \mathrm{RR}: 1.176(1.0411 .311) \\
\mathrm{NAF}: 0 \_7 \mathrm{RR}: 1.373(1.2831 .470)\end{array}$ & 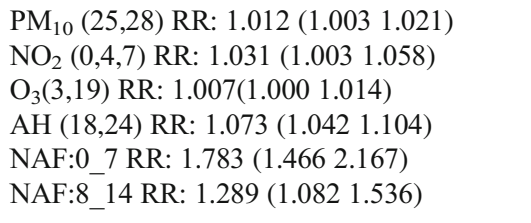 \\
\hline Palma de Mallorca & $\begin{array}{l}\mathrm{PM}_{10}(0) \mathrm{RR}: 1.004(1.0031 .005) \\
\mathrm{NO}_{2}(0,28) \mathrm{RR}: 1.059(1.0171 .102) \\
\text { Tmax (8) RR: } 1.039(1.0321 .046) \\
\text { AH (14,21) RR: } 1.102(1.0491 .156) \\
\text { NAF:0_7 RR: } 1.193(1.0601 .342)\end{array}$ & $\begin{array}{l}\mathrm{NO}_{2}(7,27) \text { RR: } 1.049(1.0021 .096) \\
\mathrm{O}_{3}(20) \text { RR: } 1.006(1.0021 .012) \\
\mathrm{AH}(18,23) \text { RR: } 1.071(1.0571 .086)\end{array}$ \\
\hline
\end{tabular}

The relative risks $(\mathrm{RR})$ are calculated for increases of $1 \mu \mathrm{g} / \mathrm{m}^{3}$ for the concentrations of $\mathrm{NO}_{2}, \mathrm{PM}_{10}$, and $\mathrm{O}_{3}$; of $1{ }^{\circ} \mathrm{C}$ for the values of Tmax and of $1 \mathrm{~g} / \mathrm{m}^{3}$ for the values of AH. For the variable NAF, the RR corresponds to an increase of one unit in the value of NAF

arriving in each of the regions analyzed in this study explain the percentage of days with advection registered in the different regions. This is shown in Table 1 (Russo et al. 2020).

Saharan dust intrusions contribute significantly to increasing levels of $\mathrm{PM}_{10}$ in the Mediterranean basin (Querol et al.
2009), which means that the concentrations of this pollutant experience an important increase even in urban air pollution measurement stations (Salvador et al. 2013), and especially in places like Las Palmas de Gran Canaria (Díaz et al. 2017; Viana et al. 2014), where there is practically a three-fold 
increase in $\mathrm{PM}_{10}$ on days with Saharan dust. These results agree with the results of other studies.

Days with Saharan dust intrusion not only produce increases in concentrations of $\mathrm{PM}_{10}$, they also result in increases in the concentrations of other pollutants such as $\mathrm{O}_{3}$. These results coincide with what has been found in other studies that analyze the evolution of pollutants on days with and without Saharan dust intrusion in the cities of Barcelona (Pandolfi et al. 2014) and Madrid (Salvador et al. 2019) and in other Spanish cities (Moreira et al. 2020). According to these studies, the reason for this increase is the existence of particulate matter on days with Saharan dust intrusion, which produces a decrease in the convective turbulence processes that cause a vertical development of the mixing layer during the day. Thus, the thickness of the mixing layer diminishes, and the concentrations of pollutants and aerosols increase ( $\mathrm{Li}$ et al. 2017).

The origin of different air masses explain the behavior detected for temperature and absolute humidity in some regions, with increases on days with Saharan intrusion (Russo et al. 2019).

One of the relevant results of this study is the association produced between the pollutant variables $\mathrm{NO}_{2}, \mathrm{PM}_{10}$, and $\mathrm{O}_{3}$ and the COVID-19 variables. There are two biological mechanisms that could explain the existence of these associations (Domigo and Rovira 2020). On the one hand, it is clear that air pollution affects human health (WHO 2013). On the other hand, Pothirat et al. (2019) investigated the association between daily average seasonal air pollutants and daily mortality of hospitalized patients and community dwellers, as well as emergency and hospitalization visits for serious respiratory, cardiovascular, and cerebrovascular diseases. It was found that air pollutants were associated with higher mortality in hospitalized patients and community dwellers, with varying effects on severe acute respiratory, cardiovascular, and cerebrovascular diseases. In relation to the age of the individuals who are affected by outdoor air pollution - in particular those with respiratory system issues - those of elderly ages are one of the most sensitive groups (Jiménez et al. 2011; Simoni et al. 2015; Kotaki et al. 2019). Thus, air pollution worsens the same type of pathology in the same vulnerable age groups that are impacted more severely by SARS-Cov2 (MSCBS 2020).

The other mechanism is based on the fact that air pollution weakens the immune system in the short term. There is growing evidence that pollution can cause oxidative stress, resulting in the production of free radicals, which in turn may damage the respiratory system and reduce the resistance to viral and bacterial infections (Ciencewicki and Jaspers 2007). Air pollutants could influence the immune system and affect its ability to limit the spread of infectious agents like respiratory syncytial virus (RSV) (Vandini et al. 2013; Nenna et al. 2017; Contini and Costabile 2020). On the other hand, Zhao et al. (2016) established that short-term exposure to $\mathrm{PM}_{2.5}$ could act on the balance of inflammatory M1 and anti-inflammatory M2 macrophage polarizations, which could be involved in air pollution-induced immune disorders and diseases.

The results found in this study, with associations in the very short term, even in lags 0 and 3, point to a worsening of preexisting circulatory and respiratory pathologies. The associations observed in the later lags could be explained by the worsening of prior conditions as well as a possible weakening of the immune system that would favor infection by the virus.

The fact that the concentrations of $\mathrm{NO}_{2}$ show a greater association with COVID-19 variables compared to $\mathrm{PM}_{10}$ and $\mathrm{O}_{3}$ concentrations is according with the fact that the impact on short-term mortality in Spain is greater for $\mathrm{NO}_{2}$ (RR: 1.012 (1.010 1.014)) (Linares et al. 2018) than for $\mathrm{PM}_{10}$ (RR: 1.009 (1.006 1.011)) (Ortiz et al. 2017). Moreover, attributable mortality at the short term in Spain for ozone is lower than the corresponding to $\mathrm{NO}_{2}$ and $\mathrm{PM}_{10}$ (Díaz et al. 2018).

In terms of the meteorological variables, the GLM models show that the coefficients related to COVID-19 variables are negative. That is to say, low and humid temperatures are related to higher incidence rates. On the other hand, the serological study of the prevalence of SARS-CoV-2 in Spain (ENECOVID) (Pollán et al. 2020) indicates that a lower prevalence of COVID-19 in Spain was produced in coastal regions that, during the time of the study and in general, are characterized by higher temperatures and humidity than the interior areas of the peninsula (AEMET 2020).

Beyond the role of air pollution or the meteorological variables included in the multivariate models, the days with Saharan dust intrusion produce a generalized increase in the rate of incidence and in COVID-19 hospital admissions in particular, which are also subject to the effect of NAF. One possible explanation of this additional effect of Saharan dust could be that there may be another possible mechanism related to the transmission of the virus. According to a study carried out in Lombardia (Setti et al. 2020), traces of RNA of SARSCoV-2 were found in samples of PM measured both in industrial and urban settings in Bergamo. The authors suggest that the aerosol particles that contain the virus of between 0.1 and $1 \mu \mathrm{m}$ can travel further when they group together with pollutant particles of up to $10 \mu \mathrm{m}\left(\mathrm{PM}_{10}\right)$. Given that the resulting particle is larger and a less dense respiratory droplet, the time it remains in the atmosphere could increase. However, other research also carried out in Italy (Bontempi 2020; Collivignarelli et al. 2021; Chirizzi et al. 2021) and in other countries (Liu et al. 2020; Dunker et al. 2021; Passos et al. 2021) suggests the opposite in terms of the possible transmission of the virus via particulate matter. In addition, a specific probabilistic analysis of the interaction of viral particles with pre-existing particles was done, showing that the interaction is essentially not happening, so that seems unreasonable to speak of $\mathrm{PM}_{10}$ as vector of SARS-CoV-2 according to the 
a)

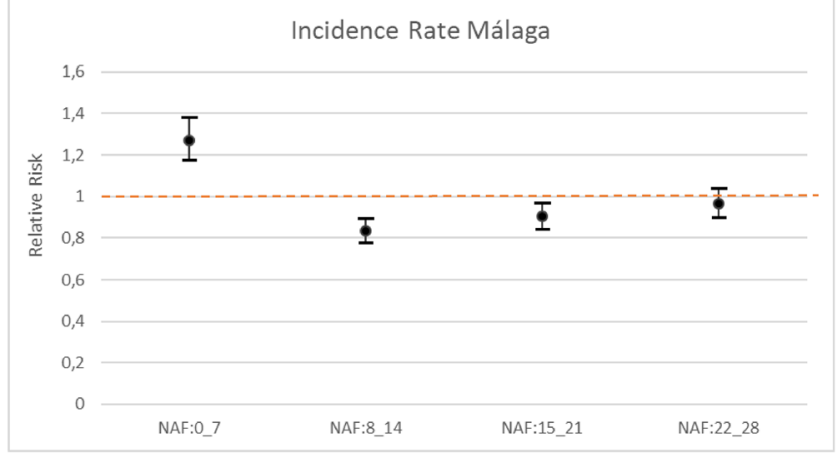

c)

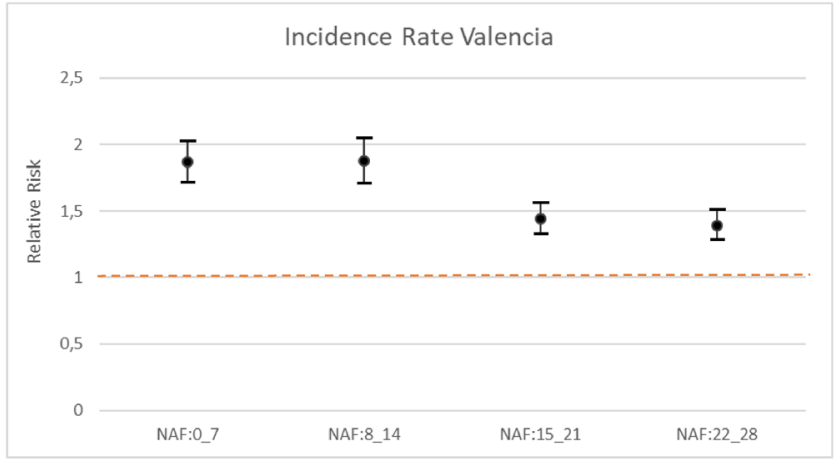

e)

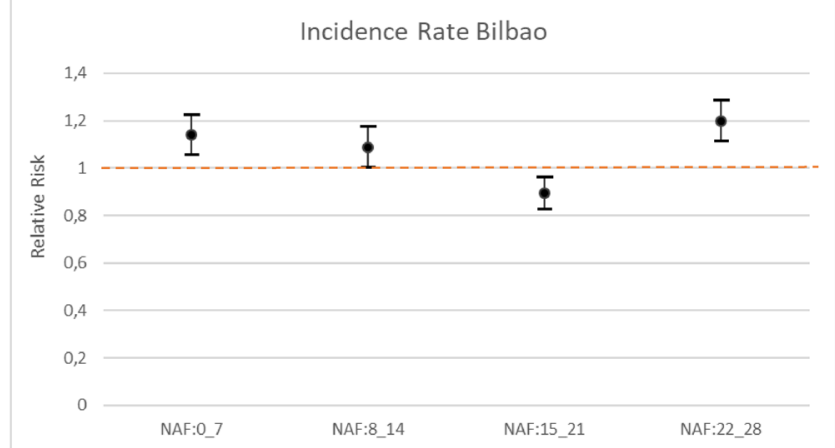

g)

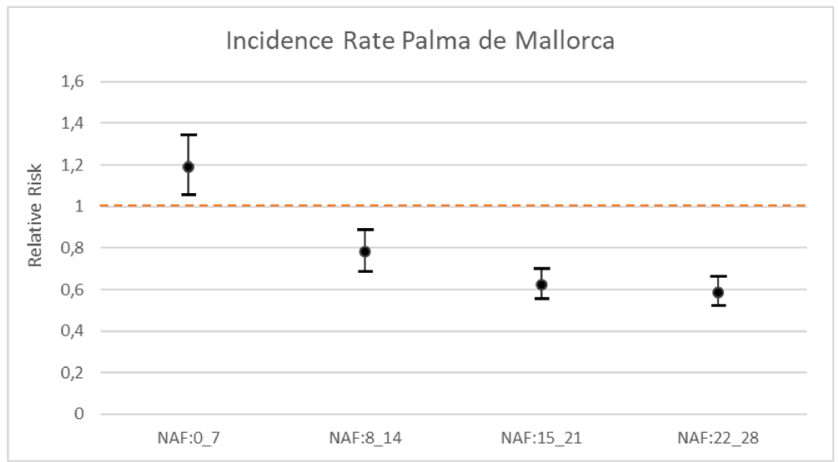

b)

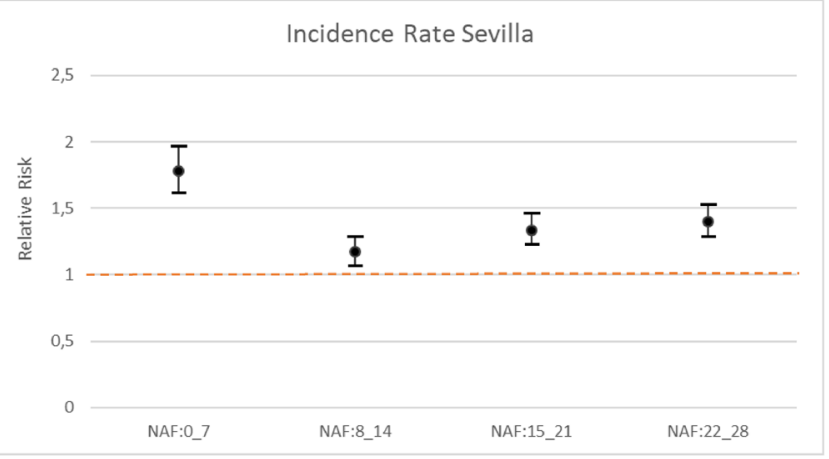

d)

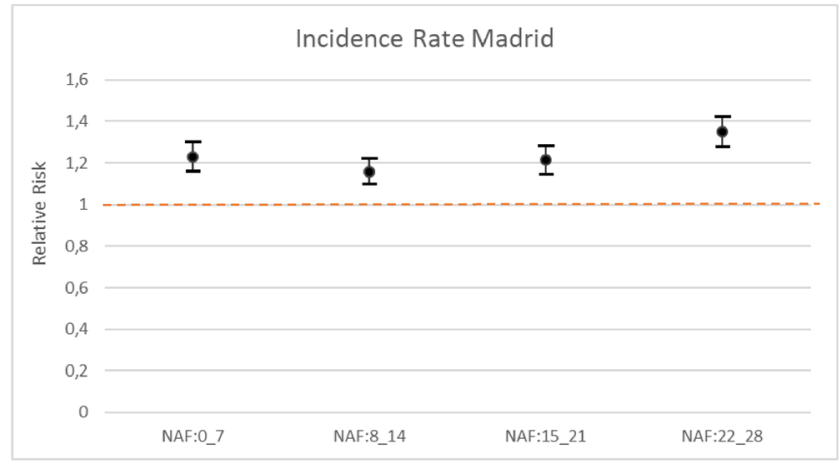

f)

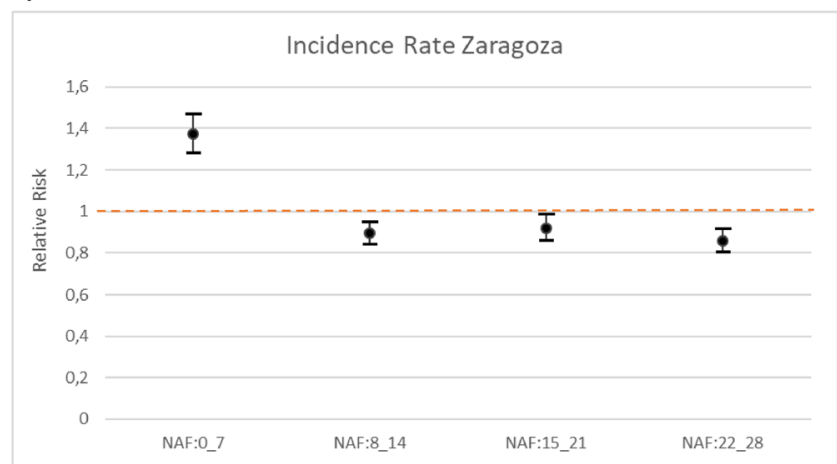


Fig. 2 Relative risks obtained for the COVID-19 incidence rate for the different lags corresponding to Saharan dust intrusion, only in regions with statically significant findings. NAF:0_7 corresponds to the average value of the first 7 days of advection of Saharan dust. NAF:8 14 corresponds to the average value of the interval of 8 to 14 days after the Saharan dust advection. NAF:15_21 corresponds to the average value of the interval of 15 to 21 days after the Saharan dust advection. NAF:22_28 corresponds to the average value of the interval of 22 to 28 days after the Saharan dust advection

a)

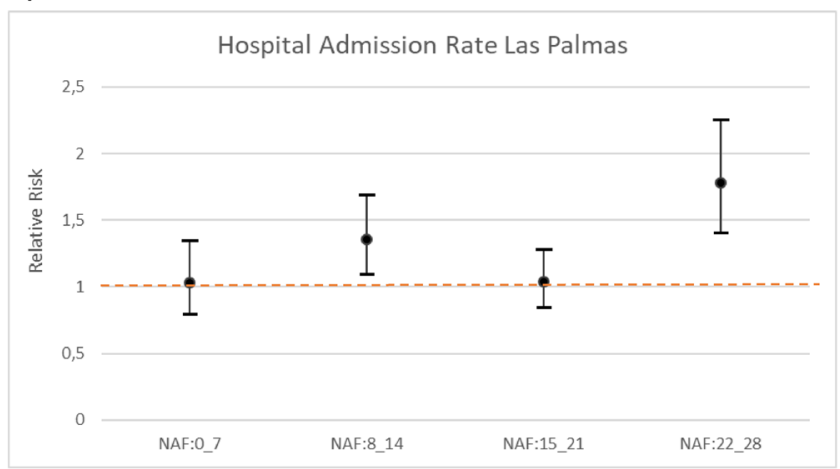

c)

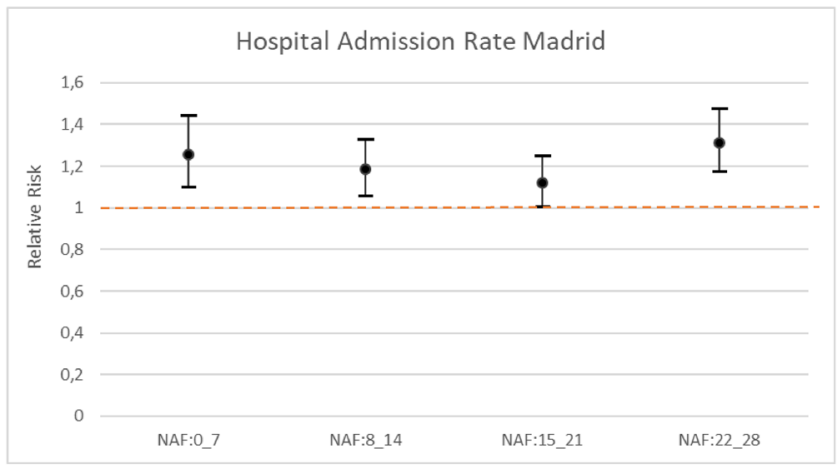

e)

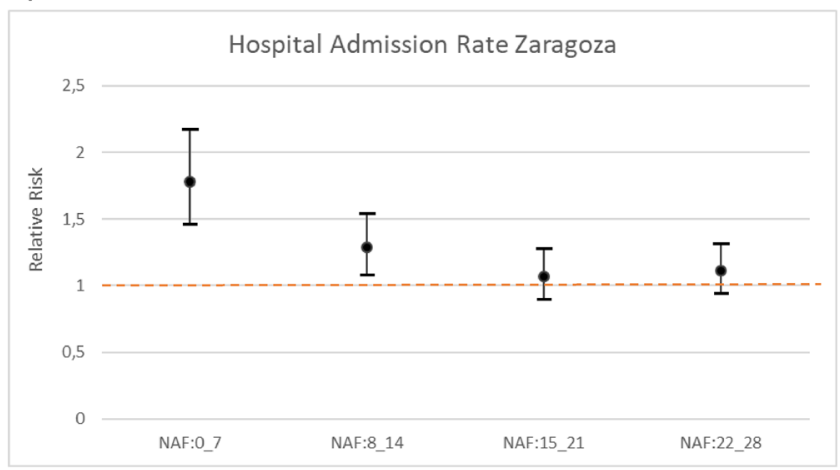

Fig. 3 Relative risks obtained for the rate of hospital admissions for COVID-19 for the lags corresponding to the intrusion of Saharan dust, only in regions with statically significant findings. NAF:0_7 corresponds to the average value of the first 7 days of advection of Saharan dust. NAF:8_14 corresponds to the average value of the interval of 8 to 14 majority of the experimental and numerical evidences (Belosi et al. 2021).

The results found in our study, with a very short-term effect in some cases (lags 0-7), lower even than the virus incubation period of 5.2 days, does not support the hypothesis that PM can act as a vector for the virus. Rather, these results point to the possibility that days with Saharan dust advection could aggravate cardiovascular and respiratory conditions, as suggested in other studies (Stafoggia et al. 2016; Díaz et al. 2017).

b)

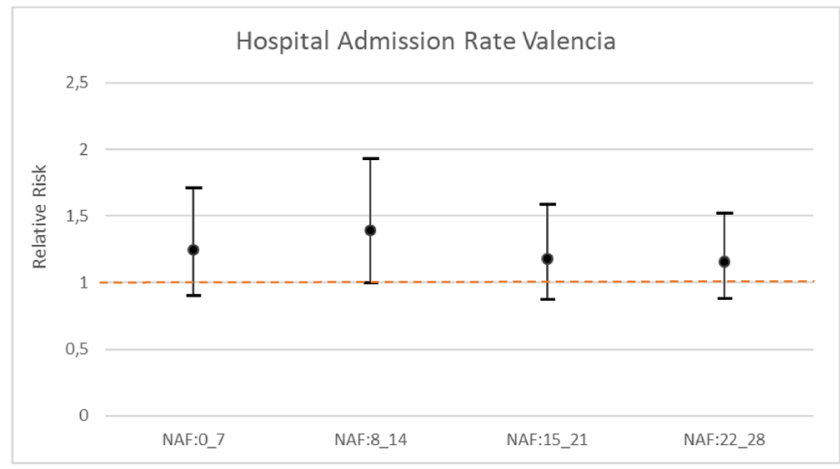

d)

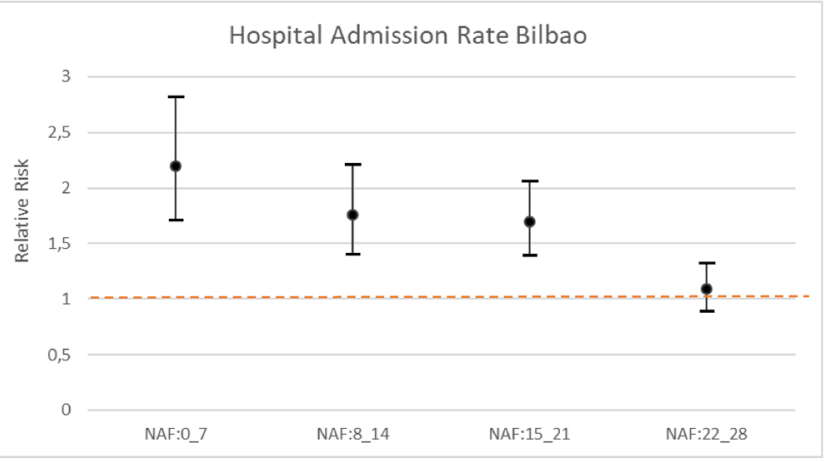

days after the advection of Saharan dust. NAF:15 21 corresponds to the average value of the interval of 15 to 21 days after the Saharan dust advection. NAF:22_28 corresponds to the average value of the interval of 22 to 28 days after the advection of Saharan dust 
One possible hypothesis that would explain why days with Saharan dust intrusion result in an exacerbation of the effect of the COVID-19 variables analyzed relates to the different composition of the particles and their reaction to the primary pollutants present in the urban atmosphere. Saharan dust particles are mineral in origin, and they are the result of stone erosion (Griffin 2007). Their chemical composition includes mineral elements such as quartz $(60 \%)$, oxides $\left(\mathrm{SIO}_{2}, \mathrm{FeO}_{2}\right)$, carbonates $\left(\mathrm{CaCO}_{3}\right)$, steel, titanium, and vanadium, and in some cases sulfate peaks can appear, resulting from the chemical reaction between carbonate contained in the dust and the gases that result from locally present environmental pollution $\left(\mathrm{NO}_{2}\right.$ $\mathrm{SO}_{2}$ ) (Tobias et al. 20111). Some studies in experimental toxicology in rats have shown that quartz, silica, aluminum, and oxides contained in desert dust can cause bronchial and lung inflammation thanks to the hyper production of cytokines (Ichinose et al. 2008; Mancino et al. 1984). In the majority of patients severely affected by COVID-19, an increase was observed in interleukins: 6 (IL6) and 10 (IL10). This process is referred to as a cytokine storm (Tang et al. 2020), and it can rapidly lead to worsening of symptoms and even death. Currently, it is not precisely known which environmental mechanisms could contribute to initiating a cytokine storm in some patients and not in others. From an immunological point of view, the presence of Saharan dust, together with other endogenous factors in each patient (genetic profile, age, and other still unclear factors), could support the initiation of this severe process.

Another possible hypothesis could be related to the fact that a decrease in the mixing layer is produced when there is a Saharan dust intrusion (Pandolfi et al. 2017; Salvador et al. 2019). A decrease in the mixing layer not only affects the increase in primary pollutants, including those we have included in this study, $\mathrm{PM}_{10}$ and $\mathrm{NO}_{2}$, but it also makes the dispersion of other pollutants and increase in aerosols more difficult ( $\mathrm{Li}$ et al. 2017). Therefore, in introducing the variable related to Saharan dust, it is important to take into account the effect of other pollutant substances not considered as independent variables that have been shown to be associated with COVID-19 (Frontera et al. 2020) or other constituents of $\mathrm{PM}_{10}$ such as $\mathrm{PM}_{2.5}$, that are also related to the incidence and severity of COVID-19 (Yao et al. 2020; Zhao et al. 2020; Zoran et al. 2020).

Finally, the greater RR for the NAF variables observed in this study can be explained by the fact that the range of variation in these variables is between zero and one, which does not occur for the rest of the variables considered in the multivariate models, as shown in Table 1.

\section{Strengths and weaknesses of this study}

One of the primary strengths of this study is the length of the series used. Even though it is a series of 335 days, it is longer than the majority of the series used in other studies carried out to date. The period of analysis included the first and the second waves of pandemic. In the first wave, the period analyzed corresponds to a period that was both prior to the state of alarm and during the state of alarm, which applied homogeneous restrictions to the zone of the study. Thus, the entire area considered in the study was subjected to the same conditions in terms of "physical distancing and other public health interventions" (Villeneuve and Goldberg 2020). The second wave of pandemic was much more diffuse and likely more suitable to show effects related to atmospheric variabilities such as temperature, pollution, and relative humidity.

The duration of the series allowed for us to construct generalized linear models with control variables such as trend and seasonality and the autoregressive component. The study corresponds to an ecological time series design, with all the epidemiological limitations inherent in this type of study, especially the ecological fallacy, which is a key weakness, given that we cannot know which of the possible hypotheses that relate Saharan dust intrusions with COVID-19 variables is that which truly explains the association or the association could be spurious and driven by other factors.

On the other hand, paradoxically, the length of the series is also considered a weakness, given that it is only eleven months and does not include complete annual variation. It was also a period that was totally anomalous, given the decrease in pollutants that occurred with the confinement of the population. Thus, the exposure to external environmental variables represents an important bias. On the other hand, the conditions under which the data were obtained correspond to the definition of a positive COVID-19 case as one which took place only when a person already presented important symptoms associated with the disease, especially in the first wave of pandemic.

Both of the abovementioned points require prudence in extrapolating the results of this study to time periods other than that of the study period. Later studies could analyze with greater depth the combined impact of climate variability, air pollution, and other factors extrinsic to COVID-19. Other important factors should also be considered that were not included in this study, such as patterns of social relationships, the susceptibility of the population, and surveillance data on respiratory infections, for example. The possible effect of the confounding factors mentioned is important and this fact is demonstrated by different studies conducted in Spain (Saez et al. 2020) and in other countries which are taking into account demographic density variables (Ahmadi et al. 2020; Coccia 2020) or socioeconomic variables (Pequeno et al. 2020). Our analysis used an ecological design for different regions independently; this mean, the authors cannot compare among different zones with diverse characteristics, but rather regions in which these factors do not change for each of them. Possibly, the differences in these factors between the different 
regions could explain the different behavior found in the exposure to the environmental variables considered.

The general conclusion of the manuscript is that air pollution, especially $\mathrm{NO}_{2}$ concentrations, influences the incidence and severity of COVID-19 and dust intrusions from the Sahara have an added risk component. The impact that these environmental factors have is small (in terms of relative risk) and by themselves cannot explain the behavior of the incidence and severity of COVID-19, which is explained by social distancing and public health measures not considered in our analysis; this assumption is similar to the findings founded in the First report of the WMO COVID-19 Task team (WMO 2021).

\section{Conclusions}

The results of this study show that chemical air pollution, especially $\mathrm{NO}_{2}$, is related to the incidence and severity of COVID-19 in Spain. Additionally, Saharan dust intrusions have an effect beyond that which can be attributed to air pollution. These results serve to support adoption of public health measures. These public health measures could include notices to especially vulnerable population groups such as the elderly and people with previous pathologies, advising them to limit reducing their exposure in outdoor environments. On the other hand, measures could be enabled to reduce air pollutant emissions of anthropic origin, which are increased when there are intrusions of Sahara dust, such as PM10 and $\mathrm{NO}_{2}$ (ozone precursor).

Author contribution CL: original idea of the study. Study design, elaboration, and revision of the manuscript. FB: providing and analysis of data, elaboration, and revision of the manuscript. JAL-B: providing and analysis of data, elaboration, and revision of the manuscript. YL: providing and analysis of data, elaboration, and revision of the manuscript. GS-M: epidemiological study design, elaboration, and revision of the manuscript. BH: providing and analysis of data, elaboration, and revision of the manuscript. DC: epidemiological study design, elaboration, and revision of the manuscript. JD: original idea of the study, study design, elaboration, and revision of the manuscript.

Funding The authors gratefully acknowledge the ENPY 221/20 Project grant from the Carlos III Institute of Health. This financing has been granted to Julio Díaz and Cristina Linares.

Data availability It is an ecological analysis, so the study does not involve human subjects. The data in relation to COVID-19 used in this study are subject to statistical secrecy and, therefore, are not freely available.

\section{Declarations}

Ethics approval The manuscript should not be submitted to more than one journal for simultaneous consideration. The submitted work should be original and should not have been published elsewhere in any form or language (partially or in full), unless the new work concerns an expansion of previous work.
The researchers declare that they have no conflicts of interest that would compromise the independence of this research work. The views expressed by the authors do not necessarily coincide with those of the institutions whose affiliation is indicated at the beginning of this article.

Consent to participate This study works with aggregate data; therefore, there are no individual data, and the consent to participate is not applicable.

Consent for publication This study works with aggregate data, therefore there are no individual data; therefore, the consent to publish is not applicable.

\section{References}

AEMET, (2020) Atlas climático de España. http://www.aemet.es/es/ serviciosclimaticos/datosclimatologicos/atlas climatico. Accessed 20 Nov 2020

Ahmadi M, Sharifi A, Dorosti S, Ghoushchi SJ, Ghanbari N (2020) Investigation of effective climatology parameters on COVID-19 outbreak in Iran. Sci Total Environ 729:138705. https://doi.org/10. 1016/j.scitotenv.2020.138705

Bashir MF, Bilal BM, Komal B, Bashir MA, Tan D, Bashir M (2020) Correlation between climate indicators and COVID-19 pandemic in New York. USA Science of the Total Environment 728(1):138835

Belosi F, Conte M, Gianelle V, Santachiara G, Contini D (2021) On the concentration of SARS-CoV-2 in outdoor air and the interaction with pre-existing atmospheric particles. Environ Res 193:110603. https://doi.org/10.1016/j.envres.2020.110603

Bilal, Bashir MF, Benghoul M et al (2020) Environmental pollution and COVID-19 outbreak: insights from Germany. Air Qual Atmos Health 13:1385-1394. https://doi.org/10.1007/s11869-020-00893-9

BOE (2020a). Boletín Oficial del Estado 14 de marzo de 2020. Real Decreto 463/2020. https://www.boe.es/diario_boe/txt.php?id= BOE-A-2020-3692. Accessed 16 Oct 2020

BOE (2020b). Boletin Ofical del Estado 6 de junio 2020. Real Decreto 555/2020. https://boe.es/diario_boe/txt.php?id=BOE-A-2020-5767. Accessed 16 Oct 2020

Bontempi E (2020) First data analysis about possible COVID-19 virus airborne diffusion due to air particulate matter (PM): The case of Lombardy (Italy). Environ Res 186:109639

CDC, (2020). Coronavirus Disease 2019 (COVID-19): Frequently asked questions. https://www.cdc.gov/coronavirus/2019-ncov/faq.html. Accessed 13 Jul 2020

Chirizzi D, Conte M, Feltracco M, Dinoi A, Gregoris E, Barbaro E et al (2021) SARS-CoV-2 concentrations and virus-laden aerosol size distributions in outdoor air in north and south of Italy. Environ Int 146:106255. https://doi.org/10.1016/j.envint.2020.106255

Ciencewicki J, Jaspers I (2007) Air pollution and respiratory viral infection. Inhal Toxicol 19:1135-1146

Coccia M (2020) Factors determining the diffusion of COVID-19 and suggested strategy to prevent future accelerated viral infectivity similar to COVID-19. Sci Total Environ 729:138474. https://doi.org/10. 1016/j.scitotenv.2020.138474

Collivignarelli MC, Abbà A, Caccamo FM, Bertanza G, Pedrazzani R, Baldi M, Ricciardi P, Miino MC (2021) Can particulate matter be identified as the primary cause of the rapid spread of CoViD-19 in some areas of Northern Italy? Environ Sci Pollut Res Int 2021:1-13. https://doi.org/10.1007/s11356-021-12735-x

Contini D, Costabile F (2020) Does Air pollution influence COVID-19 outbreaks? Atmosphere 11(4):377. https://doi.org/10.3390/ atmos11040377 
CSWP, (2011) Commission Staff Working Paper. Establishing guidelines for demonstration and subtraction of exceedances attributable to natural sources under the directive 2008/50/EC on ambient air quality and cleaner air for Europe, Brussels, 15.02. 2011. SEC 208 final, p. 37. 〈http://ec.europa.eu/environment/air/quality/ legislation/ pdf/sec_2011_0208.pdf .

Díaz J, Linares C, Carmona R, Russo A, Ortiz C, Salvador P, Trigo RM (2017) Saharan dust intrusions in Spain: health impacts and associated synoptic conditions. Environ Res 156:455-467. https://doi.org/ 10.1016/j.envres.2017.03.047

Díaz J, Ortiz C, Falcón I, Linares C (2018) Short-term effect of tropospheric ozone on daily mortality in Spain. Atmos Environ 187:107116. https://doi.org/10.1016/j.atmosenv.2018.05.059

Díaz J, López-Bueno JA, Culqui D, Asensio C, Sánchez-Martínez G, Linares C (2021) Does Exposure to noise pollution influence the incidence and severity of COVID-19? Environ Res 195:110766. https://doi.org/10.1016/j.envres.2021.110766

Domigo JL, Rovira J. Effects of air pollutants on the transmission and severity of respiratory viral infections. Environ Res 187. (2020); 109650 .

Dominici F, Wu X, Nethery R, Sabath B, Braun D, 2020. Exposure to air pollution and COVID-19 mortality in the United States: a nationwide crosssectional study. medRxiv

Dunker S, Hornick T, Szczepankiewicz G, Maier M, Bastl M, Bumberger $\mathrm{J}$ et al 2021 No SARS-CoV-2 detected in air samples (pollen and particulate matter) in Leipzig during the first spread. Sci Total Environ 755(Pt 1):142881

Frontera A, Cianfanelli L, Vlachos K, Landoni G, Cremona J (2020) Severe air pollution links to higher mortality in COVID-19 patients: The "double-hit" hypothesis. J Inf Secur:0163-4453. https://doi.org/ 10.1016/j.jinf.2020.05.031

Fronza R, Lusic M, Schmidt M, Lucic B (2020) Spatial-temporal variations in atmospheric factors contribute to SARS-CoV-2 outbreak. Viruses 12:588. https://doi.org/10.3390/v12060588

Griffin DW (2007) Atmospheric movement of microorganisms in clouds of desert dust and implications for human health. Clin Microbiol Rev 20:459-477

Gupta S, Raghuwanshi GS, Chandac A (2020) Effect of weather on COVID-19 spread in the US: a prediction model for India in 2020. Sci Total Environ 728:138860

Holtmann, M., Jones, M., Shah, A., Holtmann, G. (2020) Low ambient temperatures are associated with more rapid spread of COVID-19 in the early phase of the endemic, Environ Res, https://oi.org/10. 1016/j.envres.2020.109625.

Ichinose T, Yoshida S, Sadakane K, Takano H, Yanagisawa R et al (2008) Effects of Asian sand dust, Arizona sand dust, amorphous silica and aluminum oxide on allergic inflammation in the murine lung. Inhal Toxicol 20:685-694

Islam N, Shabnam S, Erzurumluoglu AM, 2020. Temperature, humidity, and wind speed are associated with lower COVID-19 incidence. medRxiv.

Jiang Y, Wu X-J, Guan Y-J (2020) Effect of ambient air pollutants and meteorological variables on COVID-19 incidence. Infect Control Hosp Epidemiol 41(9):1011-1015. https://doi.org/10.1017/ice. 2020.222

Jiménez E, Linares C, Martínez D, Díaz J (2011) Particulate air pollution and short-term mortality due to specific causes among the elderly in Madrid (Spain): seasonal differences. Int J Environ Health Res 21: 372-390

Kotaki K, Ikeda H, Fukuda T, Yuhei K, Yuki F, Kawasaki M, Wakamatsu K, Sugahara K (2019) Trends in the prevalence of COPD in elderly individuals in an air polluted city in Japan: a cross-sectional study. Int J Chronic Obstr Pulm Dis 14:791-798

Landrigan PJ, Fuller R, Acosta NJR, Adeyi O, Arnold R, Basu NN, Balde AB, Bertollini R, Bose-O'Reilly S, Boufford JI, Breysse PN, Chiles T, Mahidol C, Coll-Seck AM, Cropper ML, Fobil J, Fuster V,
Greenstone M, Haines A, Hanrahan D, Hunter D, Khare M, Krupnick A, Lanphear B, Lohani B, Martin K, Mathiasen KV, McTeer MA, Murray CJL, Ndahimananjara JD, Perera F, Potocnik J, Preker AS, Ramesh J, Rockstrom J, Salinas C, Samson LD, Sandilya K, Sly PD, Smith KR, Steiner A, Stewart RB, Suk WA, van Schayck OCP, Yadama GN, Yumkella K, Zhong M (2018) The Lancet Commission on pollution and health. Lancet 391:462e 512

Lauer SA, Grantz KH, Bi Q, Jones FK, Zheng Q, Meredith HR, Azman AS, Reich NG, Lessler J (2020) The incubation period of coronavirus disease 2019 (COVID-19) from publicly reported confirmed cases: estimation and application. Ann Intern Med 172(9):577-582

Li Z, Guo J, Ding A, Liao H, Liu J, Sun Y, Wang T, Xue H, Zhang H, Zhu B (2017) Aerosol and boundary-layer interactions and impact on air quality. Natl Sci Rev 4(6):810-833

Li X, Wang L, Shaonan Y, Yan F, Xiang L, Zhu J, Shen B, Gong Z (2020) Clinical characteristics of 25 death cases with COVID-19: a retrospective review of medical records in a single medical center, Wuhan. China Int J Infect Dis 94:128-132. https://doi.org/10.1016/ j.ijid.2020.03.053

Linares C, Falcón I, Ortiz C, Díaz J (2018) An approach estimating the short-term effect of NO2 on daily mortality in Spanish cities. Environ Int 116:18-28

Lipsitch M, Swerdlow DL, Finelli L (2020) Defining the epidemiology of Covid-19 — studies needed. N Engl J Med 382(13):1194-1196

Liu Y, Ning Z, Chen Y, Guo M, Liu Y, Gali NK, Sun L et al (2020) Aerodynamic analysis of SARS-CoV-2 in two Wuhan hospitals. Nature 582(7813):557-560. https://doi.org/10.1016/j.apenergy. 2020.115835

Magazzino C, Mele M, Schneider N (2020) The relationship between air pollution and COVID-19-related deaths: an application to three French cities. Applied Energy 279:115835

Mancino D, Vuotto ML, Minucci M (1984) Effects of a crystalline silica on antibody production to $\mathrm{T}$-dependent and $\mathrm{T}$ - independent antigens in Balb/c mice. Int Arch Allergy Appl Immuno 73:10-13

Marquès M, Rovira J, Nadal M, Domingo JL (2021) Effects of air pollution on the potential transmission and mortality of COVID-19: a preliminary case-study in Tarragona Province (Catalonia, Spain). Environ Res 192:110315. https://doi.org/10.1016/j.envres.2020. 110315

MITECO (2020). Ministerio para la Transición Ecológica. https://www. miteco.gob.es/es/. Accessed 30 Mar 2021

Moreira I, Linares C, Follos F, Sácnhez-Martínez G, Vellón JM, Díaz J (2020) Short-term effects of Saharan dust intrusions and biomass combustion on birth outcomes in Spain. Sci Total Environ 701: 134755. https://doi.org/10.1016/j.scitotenv.2019.134755

MSCBS, (2020). https://www.mscbs.gob.es/profesionales/saludPublica/ ccayes/alertasActual/nCov/documentos/20200417_ITCoronavirus. pdf. Accessed 30 Mar 2021

Nenna R, Evangelisti M, Frassanito A, Scagnolari C, Pierangeli A, Antonelli G, Nicolai A, Arima S, Moretti C, Papoff P, Villa MP, Midulla F (2017) Respiratory syncytial virus bronchiolitis, weather conditions and air pollution in an Italian urban area: an observational study. Environ Res 158:188-193

Ogen Y (2020) Assessing nitrogen dioxide (NO2) levels as contributing factor to coronavirus (COVID-19) fatality. Sci Total Environ:00489697. https://doi.org/10.1016/j.scitotenv.2020.138605

Onder G, Rezza G, Brusaferro S (2020) Case-fatality rate and characteristics of patients dying in relation to COVID-19 in Italy. J Am Med Assoc 323(18):1775-1776. https://doi.org/10.1001/jama.2020.4683

Ortiz C, Linares C, Carmona R, Díaz J (2017) Evaluation of short-term mortality attributable to particulate matter pollution in Spain. Environ Pollut 224:541-551

Pandolfi M, Tobias A, Alastuey A, Sunyer J, Schwartz J, Lorente J, Pey J, Querol X (2014) Effect of atmospheric mixing layer depth variations 
on urban air quality and daily mortality during Saharan dust outbreaks. Sci Total Environ 494-495:283-289

Passos RG, Silveira MB, Abrahão JS (2021) Exploratory assessment of the occurrence of SARS-CoV-2 in aerosols in hospital facilities and public spaces of a metropolitan center in Brazil. Environ Res 195: 110808. https://doi.org/10.1016/j.envres.2021.110808

Pequeno P, Mendel B, Rosa C, Bosholn M, Souza JL, Baccaro F, Barbosa R, Magnusson W (2020) Air transportation, population density and temperature predict the spread of COVID-19 in Brazil. PeerJ 8:e9322. https://doi.org/10.7717/peerj.9322

Pérez L, Tobías A, Querol X, Pey J, Alastuey A, Díaz J, Sunyer J (2012) Saharan dust, particulate matter and cause specific mortality: A Case-Crossover study in Barcelona (Spain). Environ Int 48:150155. https://doi.org/10.1016/j.envint.2012.07.001

Pollán M, Pérez-Gómez B, Pastor-Barriuso R, Oteo J, Hernán MA, Pérez-Olmeda $\mathrm{M}$ et al (2020) Prevalence of SARS-CoV-2 in Spain (ENE-COVID): a nationwide, population-based seroepidemiological Study. Lancet 396:535-544

Pothirat C, Chaiwong W, Liwsrisakun C, Bumroongkit C, Deesomchok A, Theerakittikul T, Limsukon A, Tajarernmuang P, Phetsuk N (2019) Acute effectsof air pollutants on daily mortality and hospitalizations due to cardiovascular and respiratory diseases. J Thorac Dis 11:3070

Querol X, Alastuey A, Pey J, Pandolfi M, Cusack M, Pérez N, Viana M, MorenoT, Mihalopoulos, N, Kallos G, Kleanthous S (2009) African dust contributions to mean ambient PM10 mass-levels across the Mediterranean Basin. Atmos Environ 43(28):4266-4277

Remuzzi A, Remuzzi G (2020) COVID-19 and Italy: what next? Lancet 395(10231):1225-1228. https://doi.org/10.1016/S0140-6736(20) 30627-9

Russo A, Soussa PM, Durao RM, Ramos AM, Salvador P, Linares C, Díaz J, Trigo RM (2020) Saharan dust intrusions in the Iberian Peninsula: predominant synoptic conditions. Sci Total Environ 717:137041. https://doi.org/10.1016/j.scitotenv.2020.137041

Saez M, Tobias A, Barceló MA (2020) Effects of long-term exposure to air pollutants on the spatial spread of COVID-19 in Catalonia, Spain. Environ Res 191:110177. https://doi.org/10.1016/j.envres. 2020.110177

Sajadi MM, Habibzadeh P, Vintzileos A, Shokouhi S, Miralles-Wilhelm F and Amoroso A. (2020) Temperature, humidity and latitude analysis to predict potential spread and seasonality for COVID-19. Available at SSRN: https://ssrn.com/abstract=3550308 or https:// doi.org/10.2139/ssrn.3550308. Accessed 25 Oct 2020

Salvador P, Artíñano B, Molero F, Viana M, Pey J, Alastuey A, Querol X (2013) African dust contribution to ambient aerosol levels across central Spain: characterization of long-range transport episodes of desert dust. Atmos Res 127:117-129

Salvador P, Molero F, Fernández AJ, Tobías A, Pandolfi M et al (2019) Synergistic effect of the occurrence of African dust outbreaks on atmospheric pollutant levels in the Madrid metropolitan area. Atmos Res 226:208-218

Setti L, Passarini F, De Genari G et al (2020) The potential role of particulate matter in the spreading of COVID-19 in Northern Italy: first evidence-based research hypotheses. BMJ. https://doi.org/10.1101/ 2020.04.11.20061713

Simoni M, Baldacci S, Maio S, Cerrai S, Sarno G, Viegi G (2015) Adverse effects of outdoor pollution in the elderly. J Thorac Dis 7: $34-45$

Sohrabi C, Alsafi Z, O’Neill N, Khan M, Kerwan A, Al-Jabir A, Iosifidis C, Agha R (2020) World Health Organization declares global emergency: a review of the 2019 novel coronavirus (COVID-19). Int J Surg 76:71e76. https://doi.org/10.1016/j.ijsu.2020.02.034
Stafoggia M, Zauli-Sajani S, Pey J, Samoli E, Alessandrini E, Díaz J et al (2016) Desert dust outbreaks in Southern Europe: contribution to daily PM10 concentrations and short-term associations with mortality and hospital admissions. Environ Health Perspect 124:413-419. https://doi.org/10.1289/ehp.1409164

Tang Y, Liu J, Zhang D, Xu Z, Ji J, Wen C (2020) Cytokine storm in COVID-19: the current evidence and treatment strategies. Front Immunol 11:1708. Published 2020 Jul 10. https://doi.org/10.3389/ fimmu.2020.01708

Tobías A, Molina T (2020) Is temperature reducing the transmission of COVID-19? Environ Res 186:109553

Tobias A, Perez L, Diaz J, Linares C, Pey J et al (2011) Short-term effects of particulate matter on total mortality during Saharan dust outbreaks: a case-crossover in Madrid (Spain). Sci Total Environ 412:386-389

Travaglio M, Yu Y, Popovic R, Selley L, Leal NS, Martins LM (2021) Links between air pollution and COVID-19 in England. Environmental Pollution, 268, Part A:115859.https://doi.org/10. 1016/j.envpol.2020.115859, http://www.sciencedirect.com/science/ article/pii/S0269749120365489. Accessed 2 April 2021

Vandini S, Corvaglia L, Alessandroni R, Aquilano G, Marsico C, Spinelli M, Lanari M, Faldella G (2013) Respiratory syncytial virus infection in infants and correlation with meteorological factors and air pollutants. Ital J Pediatr 39:1

Viana M, Pey J, Querol X, Alastuey A, de Leeuw F, Lükewille A (2014) Natural sources of atmospheric aerosols influencing air quality across Europe. Sci Total Environ 72:825-833

Villeneuve PJ, Goldberg MS (2020) Methodological considerations for epidemiological studies of air pollution and the SARS and COVID19 coronavirus outbreaks. Environ Health Perspect 128(9):095001. Published 2020 Sep 9. https://doi.org/10.1289/EHP7411

Wang J, Tang K, Feng K, Lin X, Lv Weifeng, Chen K, Wang F (2021) Impact of temperature and relative humidity on the transmission of COVID-19: amodelling study in China and the United States. BMJ Open 11(2):e043863. https://doi.org/10.1136/bmjopen-2020043863

WHO $(2013,2013)$ WHO Regional Office for Europe. Review of evidence on health aspects of air pollution -REVIHAAP Project Technical Report. Copenhage

WMO, (2021). First report of the WMO COVID-19 Task team. Review on meteorological and air quality factors affecting the COVID-19 pandemic. World Meteorological Association 2021. WMONo.1262. https://library.wmo.int/doc_num.php?explnum_id= 10555.

Xie J, Zhu Y (2020) Association between ambient temperature and COVID-19 infection in 122 cities from China. Sci Total Environ: 0048-9697. https://doi.org/10.1016/j.scitotenv.2020.138201

Yao Y, Pan J, Wang W, Liu Z et al (2020) Association of particulate matter pollution and case fatality rate of COVID-19 in 49 Chinese cities. Sci Total Environ:0048-9697. https://doi.org/10.1016/j. scitotenv.2020.140396

Zhao Q, Chen H, Yang T, Rui W, Liu F, Zhang F, Zhao Y, Ding W (2020) Direct effects of airborne PM2.5 exposure on macrophage polarizations. Biochim. Biophys. Acta 1860:2835-2843

Zoran MA, Savastru RS, Savastru DM, Tautan MN (2020) Assessing the relationship between surface levels of PM2.5 and PM10 particulate matter impact on COVID-19 in Milan. Italy Science of The Total Environment. https://doi.org/10.1016/j.scitotenv.2020.139825

Publisher's note Springer Nature remains neutral with regard to jurisdictional claims in published maps and institutional affiliations. 